\title{
The Effects of Titanium Topography and Chemical Composition on Human Osteoblast Cell
}

\section{Magdalena LUKASZEWSKA-KUSKA ${ }^{1}$, Przemyslaw WIRSTLEIN ${ }^{2}$, Radomir MAJCHROWSKI ${ }^{3}$, Barbara DOROCKA-BOBKOWSKA ${ }^{1}$}

${ }^{1}$ Department of Gerodontology and Oral Pathology, University of Medical Sciences Poznan, Poznan, Poland, ${ }^{2}$ Division of Reproduction, Department of Gynecology and Obstetrics, Poznan University of Medical Sciences, Poznan, Poland, ${ }^{3}$ Division of Metrology and Measurement Systems, Institute of Mechanical Technology, Poznan University of Technology, Poznan, Poland

Received October 2, 2020

Accepted February 17, 2021

Epub Ahead of Print May 12, 2021

\section{Summary}

The objective of this study was to evaluate and compare titanium surfaces: machined (MA); sintered ceramic-blasted (HAS); sintered ceramic-blasted and acid-etched (HAS DE) and to determine the effects of surface topography, roughness and chemical composition on human osteoblast cell reaction. Titanium surface samples were analyzed with respect to surface chemical composition, topography, and roughness. The effects of material surface characteristics on osteoblasts was examined by analyzing osteoblast morphology, viability and differentiation. Osteoblasts cultured on these materials had attached, spread and proliferated on every sample. The viability of osteoblasts cultured on HAS and HAS DE samples increased more intensively in time comparing to MA sample. The viability of osteoblast cultured on HAS samples increased more intensively in the early phases of culture while for cells cultured on HAS DE the cells viability increased later in time. Alkaline phosphate activity was the highest for the cells cultured on HAS sample and statistically higher than for the MA sample. The least activity occurred on the smooth MA sample along with the rougher HAS DE samples. All the examined samples were found to be biocompatible, as indicated by cell attachment, proliferation, and differentiation. Titanium surfaces modification improved the dynamics of osteoblast viability increase. Osteoblast differentiation was found to be affected by the etching procedure and presence of $\mathrm{Ca}$ and $\mathrm{P}$ on the surface.

\section{Key words}

Surface characterization - Titanium • Osteoblast • Calcium • Phosphate

\section{Corresponding author}

B. Dorocka-Bobkowska, Department of Gerodontology and Oral Pathology, University of Medical Sciences Poznan, Bukowska 70, 60-812 Poznan, Poland. E-mail: b.dorocka@ump.edu.pl

\section{Introduction}

Modern dental implantology requires rapid implant loading with a prosthodontic appliance for a functional and aesthetic result. Osseointegration as a bond between the bone and the implant is an essential condition for successful implant loading, which is largely facilitated by the implant surface. Thus, various methods, have been developed to accelerate osseointegration, such as surface chemical modification, surface topography regulation, among others (Wu et al. 2015, Xavier et al. 2003, Nicolas-Silvente et al. 2020).

The development of bone-implant interface depends on the direct interactions of the bone matrix and osteoblasts with the implant. As the implant surface interacts with the bone it influences osseointegration by altering the adhesion, spreading, growth, viability and differentiation of the cells (Xavier et al. 2015, Barradas et al. 2012, Feng et al 2004, Sunarso et al. 2016, RizoGorrita et al. 2020). The surface chemical composition and topography are known to alter these biological interactions (Xavier et al. 2003, Feng et al. 2004, Le Guehennec et al. 2008, Bretschneider et al. 2020, Lukaszewska-Kuska et al. 2018a, Lukaszewska-Kuska 
et al. 2018b, Lukaszewska-Kuska et al. 2019, Lukaszewska-Kuska et al. 2020). Titanium sandblasting increases the surface roughness, it also enriches the surface with blasting medium particles, while etching can remove part or all of the added by blasting particles (Xavier et al. 2003, Feng et al. 2004, Le Guehennec et al. 2008, Bretschneider et al. 2020, Lukaszewska-Kuska et al. 2018a, Lukaszewska-Kuska et al. 2020). For example surfaces roughness increases cells differentiation (Anselme and Bigerelle 2005, Kim et al. 2006) while $\mathrm{Ca}$ and $\mathrm{P}$ present on titanium surface improves cells viability (Zareidost et al. 2012).

The aim of this study was to compare osteoblastic cell behavior on various titanium surfaces with different chemical composition and topography in order to determine the influence of these combined surface features on cell reaction. Three sample groups were investigated: machined surface (MA); sintered ceramic-blasted (HAS); sintered ceramic-blasted and acid-etched (HAS DE). After characterizing the titanium surfaces, osteoblastic cell attachment, morphology, viability, and differentiation were studied using human osteoblast (NHOst) as test cells.

\section{Materials and Methods}

\section{Sample preparation}

Titanium discs were cut on a lathe from commercially pure class $4 \mathrm{~b}$ rods (G\&S Titanium Inc, USA) to produce specimens of $8 \mathrm{~mm}$ diameter and $1 \mathrm{~mm}$ thick. The titanium disc surface thus obtained was classified as-machined surfaced - MA. A machined surface blasted with a mixture of hydroxyapatite and tricalcium phosphate sintered in $1230{ }^{\circ} \mathrm{C}$ (HA $70 \%$; TCP $30 \%$ ) with particle size $300-600 \mu \mathrm{m}$ at the pressure of $6 \mathrm{kPa}$ was classified as HAS. A HA/TCP blasted surface treated with a mixture of acids $(36 \% \mathrm{HCl} / 96 \%$ $\mathrm{H}_{2} \mathrm{SO}_{4} \quad 1: 6$ ) for $10 \mathrm{~min}$ in $25^{\circ} \mathrm{C}$ was classified as HAS DE. After preparation all discs were ultrasonically washed in surfactant, followed by 2-propranol, disinfectant, and washed twice in distilled water and after packing sterilized by irradiation from an electron accelerator with a radiation dose of $25 \mathrm{kGy}$.

\section{Sample surfaces analysis}

The surface topography was analyzed using a scanning electron microscopy (Zeiss EVO 25, Carl Zeiss, Germany) with $6000 \times$ magnification. Surface roughness was evaluated with an optical profilometer
(WYKO NT1100, Veeco Instruments, USA). The presence of $\mathrm{Al}, \mathrm{Ca}, \mathrm{P}$ and $\mathrm{C}$ on the surface was analyzed by EDS (Quantax AXS, Bruker, Germany).

Cell cultures along with biochemical tests were conducted as previously described (Lukaszewska-Kuska et al. 2018a).

\section{Cell culture}

The human osteoblast cell line (NHOstOsteoblasts OGM, cryopreserved ampule, Lonza, USA) was cultured as described previously (LukaszewskaKuska et al. 2018a). Briefly, the cells were cultured in Osteoblasts Basal Medium (Lonza, USA) supplemented with fetal bovine serum, ascorbic acid, hydrocortisone21-hemisuccinate, beta-glycerophosphate gentamicin and amphotericin-B (Lonza, USA) in a humidified atmosphere containing $5 \% \quad \mathrm{CO}_{2}$ at $37{ }^{\circ} \mathrm{C}$ with daily changes of medium. The cells were detached with $0.25 \%$ Trypsin/EDTA (Lonza, USA).

\section{In-vitro cell response}

24-well culture plates (Multidish 24 \#144530, Roskilde, Denmark) were used. All tested samples along with polyester coverslip - Thermanox (Thermo Scientific, Denmark) used as controls were placed in the wells and $4 \times 10^{4}$ cells were seeded on every sample. Cells were cultured for 1, 3, 7 and 14 days.

\section{Cell morphology}

After three days of culture the osteoblasts were fixed with $2 \%$ glutaraldehyde in PBS for $24 \mathrm{~h}$, dehydrated in graded alcohols, dried and sputter-coated with gold. Specimen surfaces were examined by SEM and images in $250 \times$ and 5000× magnification were randomly chosen and recorded from each sample area.

\section{Cell viability}

After 1, 3, 7 and 14 days of cell culture on titanium discs and on plastic, viability test were performed. A solution of MTS (Promega, USA) and PMS (Promega, USA) was prepared, added to the medium and incubated. The absorbance of the resulting colored solution was measured $(\lambda=490 \mathrm{~nm})$, and the results were expressed as the sample absorbance.

\section{Total protein concentration}

After 14 days of culture on titanium discs and plastic discs, a Micro BCATM Protein Assay Kit (Thermo Scientific, USA) was used to determine the 
protein concentration. Briefly, after the removal of the medium the cells were homogenized. A series of bovine albumin (Sigma Aldrich, USA) dilutions were prepared. BCA working agent was added to every sample of the diluted bovine serum and absorbance of the solution was measured. The protein concentration was determined and expressed in $\mu \mathrm{g} / \mathrm{ml}$ with the aid of a calibration curve prepared from standard solutions of bovine serum dilutions.

\section{Alkaline phosphate activity}

After 14 days of culture on titanium and plastic discs, the medium was removed and the cells were homogenized. A BCATM Protein Assay Kit was used to assay the protein level. After determining the volume of $5 \mu \mathrm{g}$ of protein sample, p-Nitrophenyl Phosphate Liquid Substrate System (Sigma Aldrich, USA) was added. After incubation followed by reaction termination the sample absorbance was measured and ALP activity was determined of a $50 \mu \mathrm{g} / \mathrm{ml}$ sample.

\section{Statistical analysis}

The results were expressed as a mean \pm standard deviation of six-fold measurements. Comparisons of the mean values were performed with a one-way ANOVA Kruskal Wallis and Friedman tests depending on normality. The statistical significance was determined as $\mathrm{p} \leq 0.05$ using STATISTICA PL 12.0 (SYSTAT Software, Inc.) software.

\section{Results}

\section{Surfaces topography}

The scanning electron microscope (SEM) images of the MA surface displayed parallel, systematic and oriented grooves as a result of the tooling process (Fig. 1a). The image of the HAS sample showed rough surfaces with depressions, moderately sharp-edged rims along with broad flatter areas with small spherical grains (Fig. 1b). For the HAS DE sample globular irregularities were less visible and the rims were slightly less sharp (Fig. 1c).
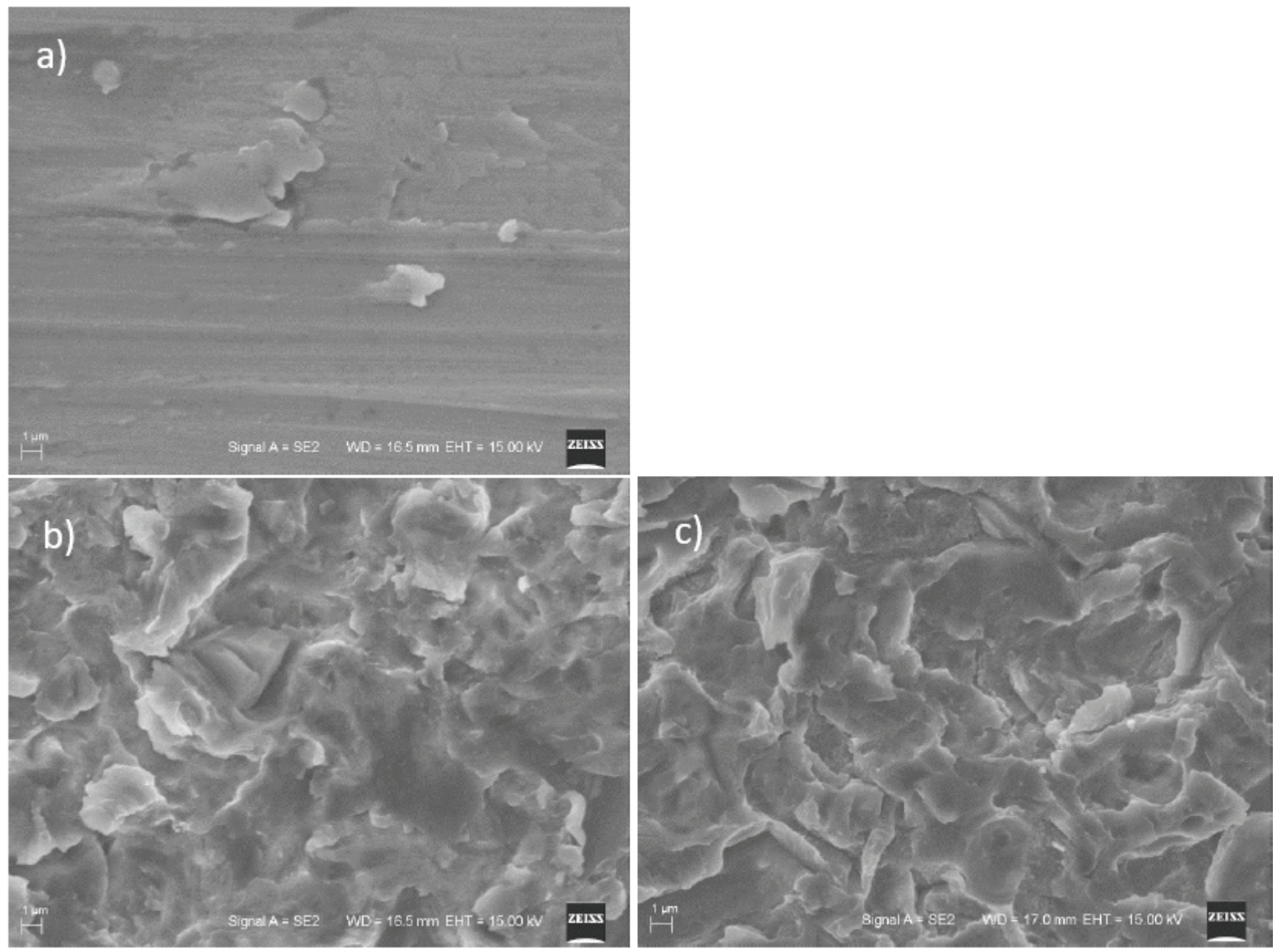

Fig. 1. Scanning electron micrographs of the tested titanium discs (a) MA sample, (b) HAS sample, (c) HAS DE sample. Original magnification 6000x; bar $=1 \mu \mathrm{m}$. 


\section{Surface chemistry}

Energy dispersive spectroscopy (EDS) was used to analyze the presence of phosphorus and calcium surface deposition from the grit-blasting procedure. For the machined sample, EDS indicated the presence of
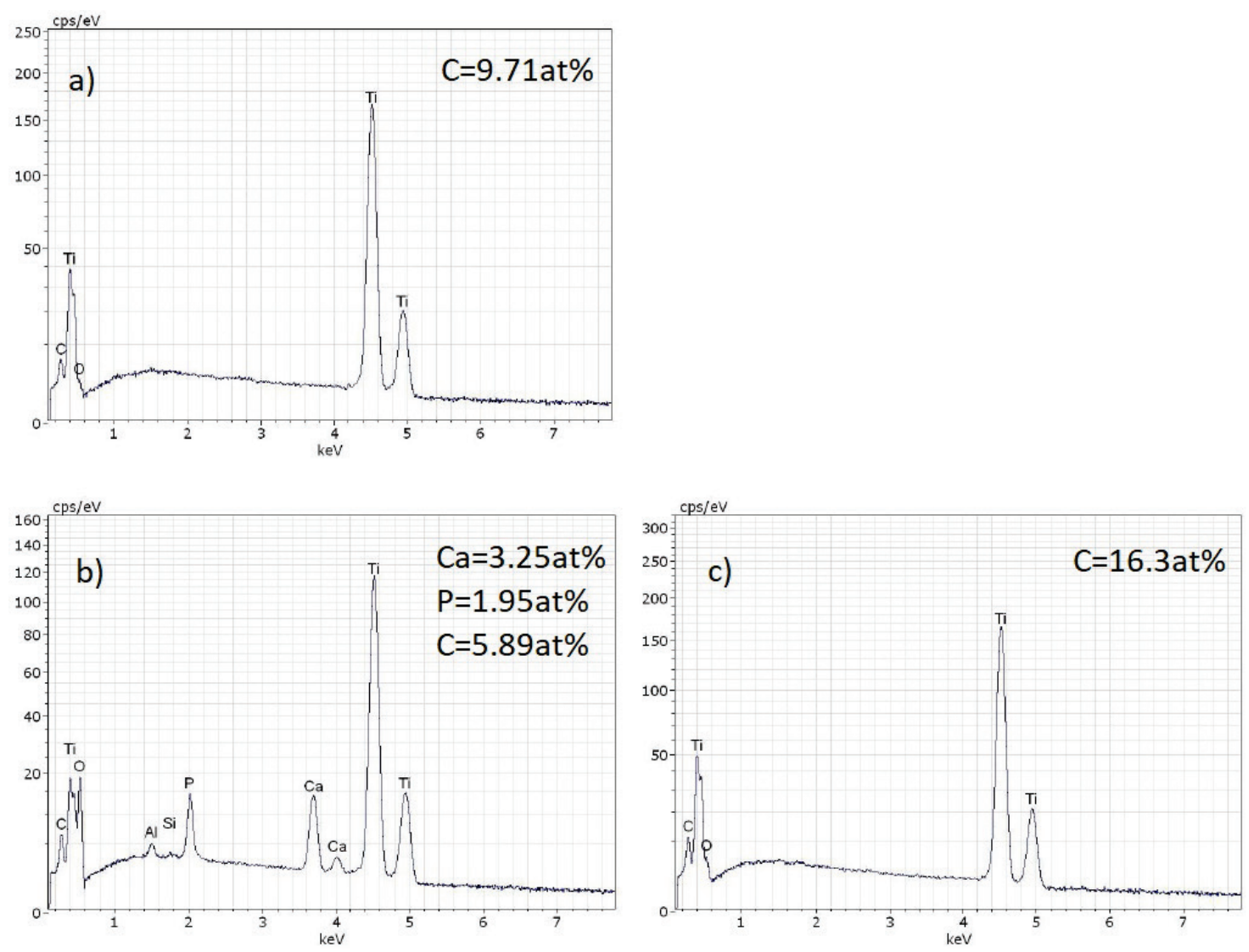

Fig. 2. Energy dispersive spectroscopy (EDS) of (a) MA sample, (b) HAS sample and (c) HAS DE sample.

\section{Surface roughness analysis}

Surface roughness analysis as indicated by amplitude parameters showed that sample HAS DE $(\mathrm{Sa}=614.26 \mathrm{~nm})$ had considerably rougher surfaces than sample MA $(\mathrm{Sa}=181.91 \mathrm{~nm})$. The percentage of additional surface area contributed by the texture compared to an ideal plane in the measured area - Sdr also revealed that the samples could be divided titanium and carbon (Fig. 2a). EDS analysis of the HAS sample revealed peaks from titanium, calcium, phosphorus, oxygen, carbon, and aluminum (Fig. 2b) while for the HAS DE sample only peaks from titanium, oxygen and carbon were present (Fig. 2c).

Table 1. Arithmetic mean of surface ordinates (Sa), surface development (Sdr), surface texture indicator (Str) measured for the tested titanium discs \pm SD.

\begin{tabular}{lccc}
\hline Sample & MA & HAS & HAS DE \\
\hline Sa (nm) & $181.91 \pm 55.77$ & $621.00 \pm 12.88$ & $614.26 \pm 57.14$ \\
Sdr (\%) & $7.13 \pm 4.15$ & $117.02 \pm 3.29$ & $79.06 \pm 6.38$ \\
Str (none) & $0.12 \pm 0.09$ & $0.84 \pm 0.01$ & $0.79 \pm 0.04$ \\
\hline
\end{tabular}




\section{Cell morphology}

SEM examination of osteoblasts cultured on materials for three days revealed that cells had attached, spread and proliferated on every sample (Fig. 3a-f).

On the MA sample osteoblasts were flatter, with a greater cell surface and in closer contact with the sample surface comparable to the cells cultured on the rougher titanium samples. They were also oriented according to grooves formed during machining (Fig. 3a-b). The osteoblasts were not oriented according to surface features on the other samples but grew parallel to each another. They also represented a smaller cell surface and less extensive contact with sample surface (Fig. 3c-f).

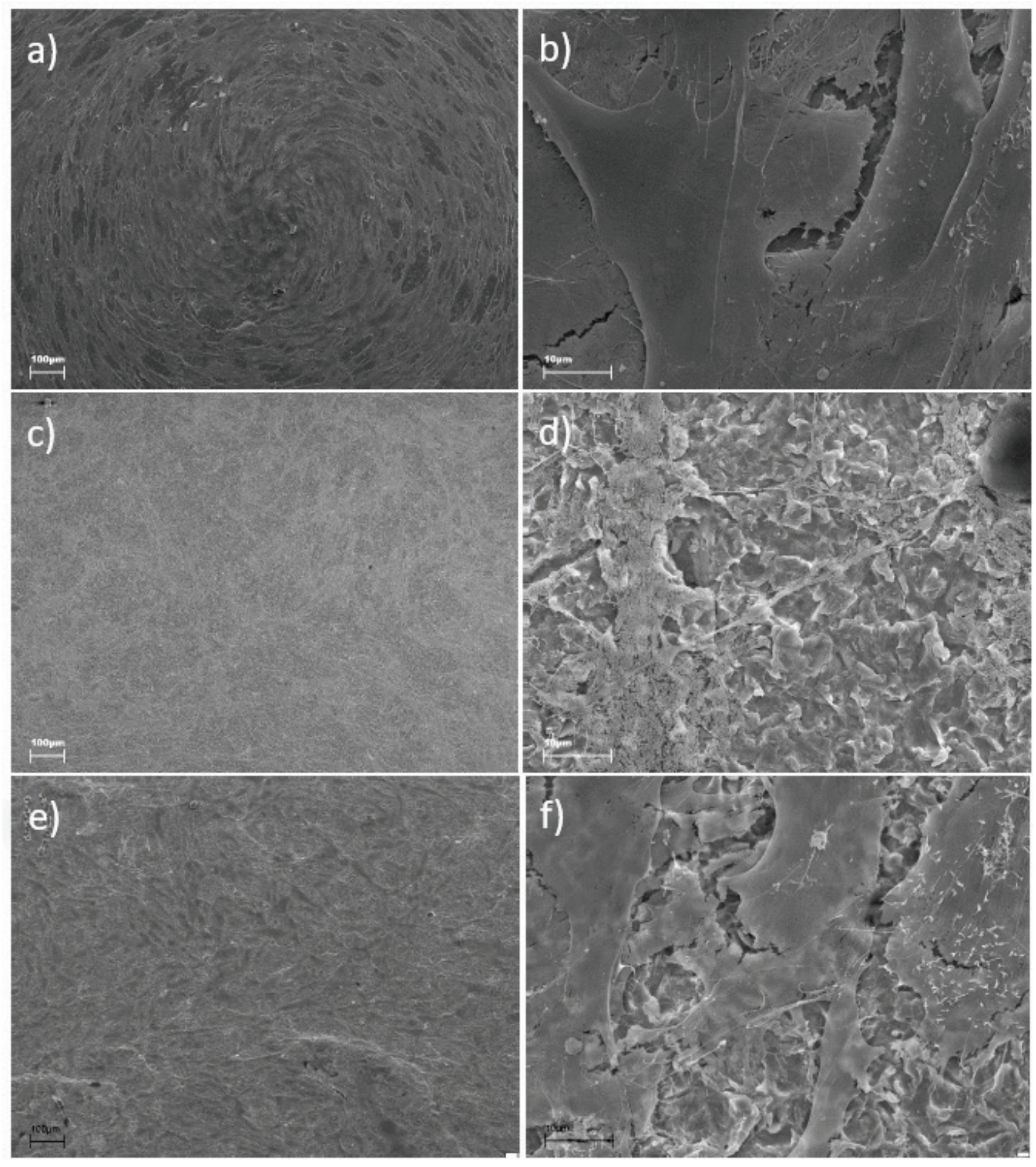

Fig. 3. SEM observation of NHOst cells morphology after 3 days of culture on (a) MA $250 \times$ magnification, bar $=100 \mu m,(\mathbf{b}) \mathrm{MA} 5000 \times$

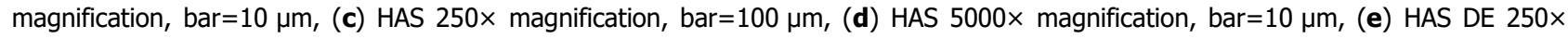
magnification, bar $=100 \mu \mathrm{m}$, (f) HAS DE 5000× magnification, bar $=10 \mu \mathrm{m}$. 


\section{Cell viability}

The osteoblast viability expressed as mitochondrial activity (MTS) after 1, 3, 7 and 14 days is presented in Fig. 4. No statistically significant differences were observed between the examined groups. All samples showed a statistically significant increase in cell viability between day 1 and 14 (plastic $p<0.05$, MA $p<0.05$, HAS and HAS DE $\mathrm{p}<0.001)$. For the HAS sample, osteoblast viability increased significantly during the first three days $(p<0.05)$ and between day 1 and $7(p<0.01)$ while for the HAS DE samples the increase occurred latter, between day 3 and 14 of culture $(p<0.05)$ and between day 1 and 7 $(\mathrm{p}<0.01)$.

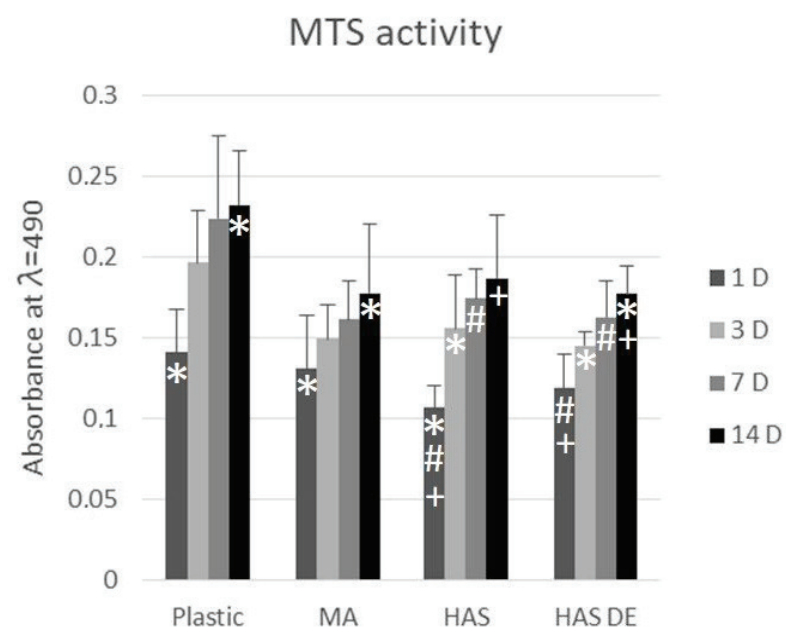

Fig. 4. The viability of NHOst cultured cells on plastic and titanium for 1, 3, 7 and 14 days expressed as sample absorbance at $\lambda=490 \mathrm{~nm}$. * indicates the two groups with statistically significant difference $p<0.05$; \# indicates the two groups with statistically significant difference $p<0.01 ;{ }^{+}$indicates the two groups with statistically significant difference $p<0.001$.

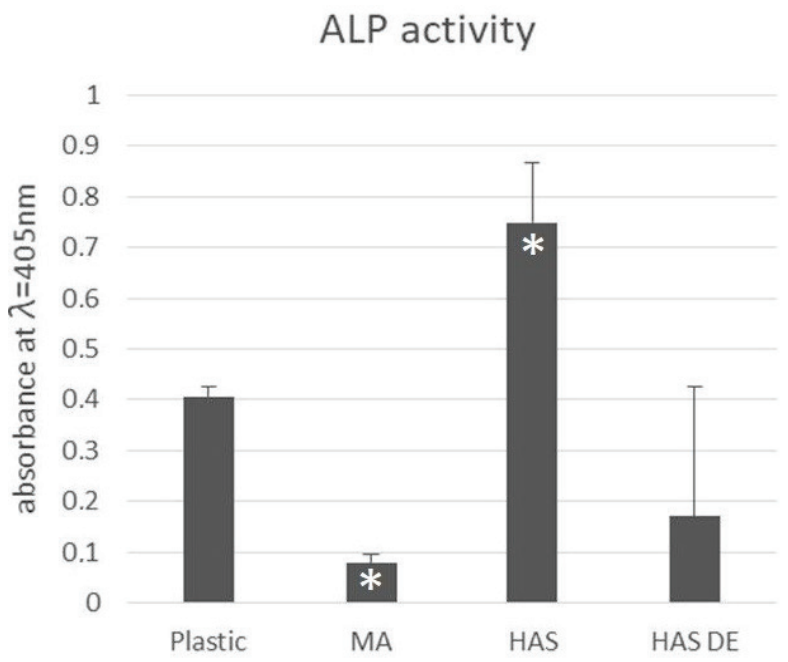

Fig. 5. Alkaline phosphate activity normalized to protein content expressed as sample absorbance at $\lambda=405 \mathrm{~nm}$ of cells cultured on plastic and titanium samples for 14 days.* indicates the two groups with statistically significant difference $p=0.001$.
Alkaline phosphate activity

Alkaline phosphate activity (ALP) of NHOst normalized to protein content is presented in Fig. 5. ALP activity was highest for the HAS sample, and statistically significantly higher than for the MA sample $(p=0.001)$. The lowest results were noted for the smooth MA sample along with the rougher HAS DE samples.

\section{Discussion}

Surface chemical composition along with surface topography are known to alter biological reactions (Xavier et al. 2003, Feng et al. 2004, Le Guehennec et al. 2008, Bretschneider et al. 2020, Lukaszewska-Kuska et al. 2018a, Lukaszewska-Kuska et al. 2018b, Lukaszewska-Kuska et al. 2019, Lukaszewska-Kuska et al. 2020, Wang et al. 2020). Aluminum in the form of $\mathrm{Al}_{2} \mathrm{O}_{3}$ is a common grit-blasting material used to increase titanium surface roughness. During the process, aluminum is incorporated into the blasted surface and enriches its chemical composition. There are different opinions of the effects of aluminum on biological response. Some authors claim a possible competitive action with $\mathrm{Ca}$, which may impair bone matrix mineralization and as a result bone formation, although this phenomenon is reported to occur in a dosedependent manner (Canabarro et al. 2008). The negative effect on the mineralization process may also be caused by other constituent ions. For example Ti as titanium ions can also inhibit the growth of hydroxyapatite (HA) in vitro (Esposito et al. 1998). In a human study concerning serum concentration of titanium and aluminum in patient with cementless primary total hip replacements serum concentrations of titanium were elevated approximately twofold in the patients who had a loose implant while no significant differences in terms of serum concentration of aluminum were observed among groups with a loose and integrated prosthesis (Jacobs et al. 1991). There are also reports on reduced osteoblast and osteoclasts activities, but this phenomenon is caused by high doses of aluminum (Jeffery et al. 1996). On the other hand, there are also reports of accelerating the rate of osteoprogenitor cell differentiation and the formation of bone nodules by aluminum resulting in greater osseointegration (Bellows et al. 1999, Yurttutan et al. 2018). Other studies show that residual aluminum oxide particles on the implant surface do not affect the osseointegration of titanium dental implant (Piatelli et al. 2003, Gehrke et al. 2018). Thus the effects of aluminum 
on the biological response, in general, remains ambiguous.

Since the aluminum influence on the bone response is ambiguous, different materials can be used for titanium grit blasting. Calcium phosphates (CPCs) are a group of materials that can be used, in place of aluminum, for roughening titanium surface. Research shows that CPCs, i.e. hydroxyapatite and tricalcium phosphates (TCP) support osteoblast adhesion and proliferation along with the stimulation of new bone formation by influencing bone marrow stromal cells and preosteoblasts differentiation into mature (Feng et al. 2004, Sunarso et al. 2016, Mastrogiacomo et al. 2006, Bin Sulaiman et al. 2013, Surmanev et al. 2014, Trávníčková and Bačáková 2018, Zofkova 2018, Zofkova and Blahos 2017, Zofkova et al. 2017). Calcium in the form of $\mathrm{Ca}^{2+}$ ions by providing positively charged surfaces facilitates fibronectin and vitronectin adsorption, cell attachment-promoting proteins, which act as osteoblasts ligands (Feng et al. 2004). $\mathrm{Ca}^{2+}$ ions also mediate cell-cell conjunction and cell-cell communication improving cell adhesion and cell activity (Feng et al. 2004, Anselme 2000). They also increase differentiation markers such as ALP activity and bone-like nodule formation (Barradas et al. 2012, Sunarso et al. 2016). $\mathrm{PO}_{4}{ }^{3-}$ ions are also capable of adsorbing proteins and osteoblasts but with the help of $\mathrm{Ca}^{2+}$ ions which work in chemical synergism with $\mathrm{PO}_{4}^{3-}$ ions (Barradas et al. 2012). Both $\mathrm{Ca}^{2+}$ and $\mathrm{PO}_{4}{ }^{3-}$ ions influence attachment, proliferation, ALP activity, and bone-nodule formation but their influence is more significant when they act together synergistically improving the cytocompatibility of the titanium surfaces (Sunarso et al. 2016).

Along with titanium surfaces grit-blasting, acidetching can be used to improve surface texture. This process can also be used to remove residual components imbedded in the titanium surface during the blasting procedure. Although titanium etching does not cause a cytotoxic cellular effect and, by altering surfaces texture, improves cell adhesion it also increases the surface carbon concentration and decreases the surface oxygen concentration which leads to a decline in surface energy that impairs osseointegration by a deteriorated regulation of the inflammatory response (Orsini et al. 2000, Hotchkiss et al. 2017). Titanium etching also causes a release of constituent ions with the Ti impairing mineralization process (Hotchkiss et al. 2017). However acid etched titanium surface was also reported as suitable candidate for healing into the bone tissue due to high osteoblast proliferation, the highest production of osteogenesis markers and low production of inflammatory cytokines and due to the most intensive blood clot formation (Kubies et al. 2011).

Surface topography, apart from surface chemical composition, influences bone response towards endosseous implants (Jokstad et al. 2003, Wennerberg and Albrektsson 2009). Moderately rough surfaces (Sa $>1-2 \mu \mathrm{m}$ ) show a stronger bone response than smooth, minimally smooth and rough surfaces (Wennerberg and Albrektsson 2009). One explanation may be that friction of smooth surfaces may be too small for proper retention and for rough surfaces only peak contact with the bone will occur (Wennerberg and Albrektsson 2009). Another explanation for a poor bone response towards smooth surfaces is the possibility of cell flattening preventing cell nutrition, for rough surfaces, on the other hand, cells recognize them as smooth since distances between peaks and valleys are relatively large (Wennerberg and Albrektsson 2009). Increased surface roughness also results in an overall increase in pro-inflammatory cytokine release impairing bone healing (OlivaresNavarrete et al. 2013). Also in long-term observations both smooth and rough implant surfaces present negative clinical results. For implants with a rough surface, a recurrent marginal infection may lead to clinical failure while for those with a smooth surface lower degree of bony contact might increase the risk of overloading and also lead to clinical failure (Esposito et al. 1998). An optimal surface for cell reaction would be a surface, which mimics the natural architecture of natural tissue with irregularities matching the size of extracellular matrix molecules and extracellular parts of cell adhesion receptors improving osteoblasts adhesion, growth and differentiation (Vandrovcová and Bačáková 2011).

As mentioned above, chemical and topographical properties have been shown to influence the osteoblast reaction in this study. In term of cells viability surface features of all the examined samples were biocompatible. More favorable surface for osteoblasts viability were HAS and HAS DE surface. The viability increased more dynamically for those rougher samples comparing to MA. The same conclusion was drawn by Wennerberg in the paper where she stated that smooth and minimally rough surfaces show a weaker bone response than rough surfaces (Wennerberg and Albrektsson 2009). Osteoblast viability increased more intensively in the initial phases in the case of HAS samples, with a developed interfacial area ratio 
around $110 \%$. The influence of $\mathrm{Ca}, \mathrm{P}$, or $\mathrm{C}$ on osteoblasts viability was not evident.

By blasting the surface with particles, the surface composition may be altered and thus, affect the biocompatibility (Xavier et al. 2003). Such an improved material characteristic can be observed in the ALP activity diagram where surfaces with incorporated $\mathrm{Ca}$ and $\mathrm{P}$ during the blasting procedure, improved cell differentiation. A positive reaction for a surface enriched with $\mathrm{Ca}$ and $\mathrm{P}$ has also been concluded by other authors (Barradas et al. 2012, Sunarso et al. 2016). For HAS sample, ALP activity is even higher than for the control, plastic material. The surfaces roughness does not seem to influence cells differentiation since ALP activity for smooth MA sample is not statistically different than for rough HAS DE sample. This result is in contrast with the previous studies, which stated that increased surfaces roughness increases alkaline phosphate activity (Anselme and Bigerelle 2005, Kim et al. 2006, Rausch-fan et al. 2008). Maybe the negative influence of etching is stronger than the positive effect of increased roughness.

The etching procedure was found to decrease osteoblast differentiation which can be caused by the removal of incorporated $\mathrm{Ca}$ and $\mathrm{P}$ during the blasting procedure. This can also be caused by increasing carbon contaminants during etching. Titanium with increased carbon content has higher contact angles and lower surface energy (Xavier et al. 2003). Titanium surfaces with high surface energy present an increased rate of osseointegration and reduced healing times due to the improved regulation of the inflammatory response generated by the high-energy surface (Xavier et al. 2003). However, reduced surface energy due to etching impairs osteoblast differentiation (Xavier et al. 2003). Also an increase in trace element impurities from Ti was observed after titanium etching which can impair osteoblast differentiation (Xavier et al. 2003). Acid treatment also decreased the surface development ratio - Sdr that could also be the reason for the decrease of osteoblast differentiation.

As for surface orientation, it does not seem to influence cell viability nor their differentiation but influences their morphology. Osteoblasts cultured on isotropic titanium surfaces were oriented according to surface features while in case of anisotropic surfaces they were aligned with respect to one another, which is in agreement with other authors' observations (Anselme and Bigerelle 2005, Anselme and Bigerelle 2006, Bigerelle et al. 2002, Dorocka-Bobkowska et al. 2017). Titanium surface roughness expressed as arithmetical mean height along with developed interfacial area ratio also influence osteoblast morphology. In the case of smoother surfaces, osteoblasts were flatter, with a greater cell surface and in closer contact with the sample surface compared to cells cultured on rougher titanium samples. Similar observations were made by other authors (Anselme and Bigerelle 2005, Anselme and Bigerelle 2006, DorockaBobkowska et al. 2017, Batzer et al. 1998, Rebl et al. 2012).

Different blasting materials used for surface roughening result in different surfaces texture and compositions. For exempla, titanium surface blasted with $\mathrm{Al}_{2} \mathrm{O}_{3}$ is rougher than blasted with sintered ceramic materials. Blasting with $\mathrm{Al}_{2} \mathrm{O}_{3}$ also enriches the titanium surface with $\mathrm{Al}$ as described in our previous work (Lukaszewska-Kuska et al. 2018a). Such surface also improves osteoblasts viability with even higher results than for HAS surface, although these differences are not statistically significant. Alumina blasted surface also statistically significantly improves ALP activity comparing to the plastic samples $(p=0.03)$ but this activity still is significantly lower than for the HAS sample $(p=0.0002)$. Such results could be explained by the beneficial influence of $\mathrm{Ca}$ and $\mathrm{P}$ of HAS sample or by its lower amplitude roughness parameters. Also, etching of alumina blasted surface causes a statistically significant decrease of osteoblasts differentiation comparing to alumina blasted surface $(p=0.006)$. The same decrease can be observed for the HAS DE surface comparing to the HAS sample suggesting the unfavorable influence of titanium etching on osteoblasts differentiation in spite of blasting medium (LukaszewskaKuska et al. 2018a).

While comparing sintered ceramics used in this study with a particle size of $300-600 \mu \mathrm{m}$ with non sintered ceramics used in our previous study having the particle size $<300 \mu \mathrm{m}$ differences in titanium surface were noted along with differences in osteoblast viability and ALP activity (Lukaszewska-Kuska et al. 2018a). Comparing cells viability in 1, 3, 7 and 14 day of culture, titanium blasted with non sintered ceramic along with titanium blasted with non sintered ceramic and etched reached higher results after 3 days compared to surfaces blasted and blasted and etched with sintered ceramics. This fact could not be explained either by surfaces roughens nor by its chemical composition. After 7 and 14 days of culture, the results for titanium blasted with sintered and non sintered ceramics were comparable. 
While comparing the rate of cell viability increase for titanium samples blasted with sintered and non sintered ceramics, it was greater for rougher, richer with $\mathrm{Ca}$ and $\mathrm{P}$ non sintered ceramic sample and occurred between days 3 and 14. Results of osteoblasts differentiation expressed in ALP activity were higher for titanium blasted with sintered ceramics than for titanium blasted with non sintered ceramics. Sample blasted with non sintered ceramic and etched had lower ALP results as sample only blasted with non sintered ceramic although those differenced were not statistically significant. Sample blasted with sintered ceramic and etched noted lower results of ALP activity from the group of sintered and non sintered ceramic blasted materials. The decrease in osteoblast differentiation for etched samples can be noted for both sintered and non sintered ceramic blasted surfaces what can be connected with $\mathrm{Ca}$ and $\mathrm{P}$ withdraw during the etching procedure along with $\mathrm{C}$ increase.

All examined samples, regardless of the topography and surface chemical composition, were found to be biocompatible, because they allowed cell attachment, proliferation, and differentiation. The surface chemical composition influenced the cell reaction in a different manner than surface topography. The rough HAS and HAS DE samples were more conducive to osteoblast viability with the surface development ratio improving cell viability in the early phases. Osteoblast differentiation was influenced by the etching procedure and improved by the presence of surface $\mathrm{Ca}$ and $\mathrm{P}$.

\section{Conflict of Interest}

There is no conflict of interest.

\section{Acknowledgements}

This research was funded by University of Medical Sciences Poznan, Poland (grant number 502-1402208321-09011).

\section{References}

ANSELME K: Osteoblast adhesion on biomaterials. Biomaterials 21: 667-681, 2000. https://doi.org/10.1016/S01429612(99)00242-2

ANSELME K, BIGERELLE M: Topography effects of pure titanium substrates on human osteoblast long-term adhesion. Acta Biomater 1: 211-222, 2005. https://doi.org/10.1016/j.actbio.2004.11.009

ANSELME K, BIGERELLE M: Effect of a gold-palladium coating on the long-term adhesion of human osteoblasts on biocompatible metallic materials. Surf Coat Tech 200: 6325-6330, 2006. https://doi.org/10.1016/j.surfcoat.2005.11.001

BARRADAS AM, FERNANDES HA, GROEN N, CHAI YC, SCHROOTEN J, VAN DE PEPPEL J, VAN LEEUWEN JPTM, VAN BLITTERSWIJK CA, DE BOER J: A calcium-induced signaling cascade leading to osteogenic differentiation of human bone marrow-derived mesenchymal stromal cells. Biomaterials 33: 3205-3215, 2012. https://doi.org/10.1016/j.biomaterials.2012.01.020

BATZER R, LIU Y, COCHRAN DL, SZMUCKLER-MONCLER S, DEAN DD, BOYAN BD, SCHWARTZ Z: Prostaglandins mediate the effects of titanium surface roughness on MG63 osteoblast-like cells and alter cell responsiveness to 1 alpha, 25-(OH)2D3. Biomed Mater Res 41: 489-496, 1998. https://doi.org/10.1002/(SICI)1097-4636(19980905)41:3<489::AID-JBM20>3.0.CO;2-C

BELLOWS CG, HEERSCHE JN, AUBIN JE: Aluminum accelerates osteoblastic differentiation but is cytotoxic in long-term rat calvaria cell cultures. Calcif Tissue Int 65: 59-65, 1999. https://doi.org/10.1007/s002239900658

BIGERELLE M, ANSELME K, NOEL B, RUDERMAN I, HARDOUIN P, IOST A: Improvement in the morphology of Ti-based surfaces: a new process to increase in vitro human osteoblast response. Biomaterials 23: 1563-1577, 2002. https://doi.org/10.1016/S0142-9612(01)00271-X

BIN SULAIMAN S, KEONG TK, CHENG CH, SAIM AB, IDRUS RBHI: Tricalcium phosphate/hydroxyapatite (TCP-HA) bone scaffold as potential candidate for the formation of tissue engineered bone. Indian J Med Res 137: 1093-1101, 2013.

BRETSCHNEIDER H, METTELSIEFEN J, RENTSCH C, GELINSKY M, LINK HD, GUNTHER KP, LODE A, HOFBAUER C: Evaluation of topographical and chemical modified TiAl6V4 implant surfaces in a weightbearing intramedullary femur model in rabbit. J Biomed Mater Res 108: 1117-1128, 2020. https://doi.org/10.1002/jbm.b.34463 
CANABARRO A, DINIZ MG, PACIORNIK S, CARVALHO L, SAMPAIO EM, BELOTI MM, ROSA AL, FISCHER RG: High concentration of residual aluminum oxide on titanium surface inhibits extracellular matrix mineralization. J Biomed Mater Res A 87: 588-597, 2008. https://doi.org/10.1002/jbm.a.31810

DOROCKA-BOBKOWSKA B, MEDYNSKI D, PRYLINSKI M: Recent advances in tissue conditioners for prosthetic treatment: A review. Adv Clin Exp Med 26: 723-728, 2017. https://doi.org/10.17219/acem/62634

EPOSITO M, HIRSCH M, LEKHOM U, THOMSEN P: Biological factors contributing to failures of osseointegrated oral implants. (II). Etiopathogenesis. Eur J Oral Sci 106: 721-764, 1998. https://doi.org/10.1046/j.0909-8836..t01-6-.X

FENG B, WENG J, YANG BC, QU SX, ZHANG X: Characterization of titanium surfaces with calcium and phosphate and osteoblast adhesion. Biomaterials 25: 3421-3428, 2004. https://doi.org/10.1016/j.biomaterials.2003.10.044

GEHRKE SA, RAMIREZ-FERNANDEZ MP, GRANERO JMM, SALLES MB, DEL FABBRO M, GUIRADO JLC: A comparative evaluation between aluminium and titanium dioxide microparticles for blasting the surface titanium dental implants: an experimental study in rabbits. Clin Oral Implants Res 29: 802-807, 2018. https://doi.org/10.1111/clr.12973

HOTCHKISS KM, AYAD NB, HYZY SL, BOYAN BD, OLIVARES-NAVARRETE R: Dental implant surface chemistry and energy alter macrophage activation in vitro. Clin Oral Implants Res 28: 414-423, 2017. https://doi.org/10.1111/clr.12814

JACOBS JJ, SKIPOR AK, BLACK J, URBAN RM, GALANTE JO: Release and excretion of metal in patients who have a total hip-replacement component made of titanium-base alloy. J Bone Joint Surg Am 73: 1475-1486, 1991. https://doi.org/10.2106/00004623-199173100-00005

JEFFERY EH, ABREO K, BURGESS E, CANNATA J, GREGER JL: Systemic aluminum toxicity: effects on bone, hematopoietic tissue, and kidney. J Toxicol Environ Health 48: 649-665, 1996. https://doi.org/10.1080/009841096161122

JOKSTAD A, BRAEGGER U, BRUNSKI JB, CARR AB, NAERT I, WENNERBERG A: Quality of dental implants. Int Dent J 53 (6 Suppl 2): 409-443, 2003. https://doi.org/10.1111/j.1875-595X.2003.tb00918.X

LE GUEHENNEC L, LOPEZ-HEREDIA MA, ENKEL P, WEISS Y, AMOURIQ Y, LAYROLLE P: Osteoblastic cell behaviour on different titanium implant surfaces. Acta Biomater 4: 535-543, 2008. https://doi.org/10.1016/j.actbio.2007.12.002

LUKASZEWSKA-KUSKA M, WIRSTLEIN P, MAJCHROWSKI R, DOROCKA-BOBKOWSKA B: Osteoblastic cell behaviour on modified titanium surfaces. Micron 105: 55-63, 2018a. https://doi.org/10.1016/j.micron.2017.11.010

LUKASZEWSKA-KUSKA M, KRAWCZYK P, MARTYLA A, HEDZELEK W, DOROCKA-BOBKOWSKA B: Hydroxyapatite coating on titanium endosseous implants for improved osseointegration: Physical and chemical considerations. Adv Clin Exp Med 27: 1055-1059, 2018b. https://doi.org/10.17219/acem/69084

LUKASZEWSKA-KUSKA M, KRAWCZYK P, MARTYLA A, HEDZELEK W, DOROCKA-BOBKOWSKA B: Effects of a hydroxyapatite coating on the stability of endosseous implants in rabbit tibiae. Dent Med Probl 56: 123-129, 2019. https://doi.org/10.17219/dmp/103851

LUKASZEWSKA-KUSKA M, IDZIOR-HAUFA M, DOROCKA-BOBKOWSKA B: Evaluation of human osteoblast metabolic activity in modified titanium-conditioned medium. Proc Inst Mech Eng H 234: 603-611, 2020. https://doi.org/10.1177/0954411920911281

KIM MJ, KIM CW, LIM YJ, HEO SJ: Microrough titanium surface affects biologic response in MG63 osteoblast-like cells. J Biomed Mater Res A 79: 1023-1032, 2006. https://doi.org/10.1002/jbm.a.31040

KUBIES D, HIMMLOVÁ L, RIEDEL T, CHÁNOVÁ E, BALÍK K, DOUDĚROVÁ M, BÁRTOVÁ J, PEŠÁKOVÁ $\mathrm{V}$ : The interaction of osteoblasts with bone-implant materials: 1 . The effect of physicochemical surface properties of implant materials. Physiol Res 60: 95-111, 2011. https://doi.org/10.33549/physiolres. 931882

MASTROGIACOMO M, SCAGLIONE S, MARTINETTI R, DOLCINI L, BELTRAME F, CANCEDDA R, QUARTO R: Role of scaffold internal structure on in vivo bone formation in macroporous calcium phosphate bioceramics. Biomaterials 27: 3230-3237, 2006. https://doi.org/10.1016/j.biomaterials.2006.01.031

NICOLAS-SILVENTE AI, VELASCO-ORTEGA E, ORTIZ-GARCIA I, MONSALVE-GUIL L, GIL J, JIMENEZGUERRERA A: Influence of the titanium implant surface treatment on the surface roughness and chemical composition. Materials 13: article ID 314, 2020. https://doi.org/10.3390/ma13020314 
OLIVARES-NAVARRETE R, HYZY SL, GITTENS RAI, SCHNEIDER JM, HAITHCOCK DA, ULLRICH PF, SLOSAR PJ, SCHWARTZ Z, BOYAN BD: Rough titanium alloys regulate osteoblast production of angiogenic factors. Spine J 13: 1563-1570, 2013. https://doi.org/10.1016/j.spinee.2013.03.047

ORSINI G, ASSENZA B, SCARANO A, PIATTELLI M, PIATTELLI A: Surface analysis of machined versus sandblasted and acid-etched titanium implants. Int J Oral Maxillofac Implants 15: 779-784, 2000.

PIATTELLI A, DEGIDI M, PAOLANTONIO M, MANGANO C, SCARANO A: Residual aluminum oxide on the surface of titanium implants has no effect on osseointegration. Biomaterials 24: 4081-4089, 2003. https://doi.org/10.1016/S0142-9612(03)00300-4

RAUSCH-FAN X, QU Z, WIELAND M, MATEJKA A, ACHEDLE A: Differentiation and cytokine synthesis of human alveolar osteoblasts compared to osteoblast-like cells (MG63) in response to titanium surfaces. Dent Mater 24: 102-110, 2008. https://doi.org/10.1016/j.dental.2007.03.001

REBL H, FINKE B, LANGE R, WELTMANN KD, NEBE JB: Impact of plasma chemistry versus titanium surface topography on osteoblast orientation. Acta Biomater 8: 3840-3851, 2012. https://doi.org/10.1016/j.actbio.2012.06.015

RIZO-GORRITA M, FERNANDEZ-ASIAN I, GARCIA-DE-FRENZA A, VAZQUEZ-PACHON C, SERRERAFIGALLO MA, TORRES-LAGARES D, GUTIERREZ-PEREZ JL: Influence of three dental implant surfaces on cell viability and bone behavior. An in vitro and a histometric study in a rabbit model. Appl Sci 10: article ID 4790, 2020. https://doi.org/10.3390/app10144790

SUNARSO, TOITA R, TSURU K, ISHIKAWA K: Immobilization of calcium and phosphate ions improves the osteoconductivity of titanium implants. Mater Sci Eng C Matter Biol Appl 68: 291-298, 2016. https://doi.org/10.1016/j.msec.2016.05.090

SURMANEV RA, SURMANEVA A, IVANOVA AA: Significance of calcium phosphate coatings for the enhancement of new bone osteogenesis--a review. Acta Biomater 10: 557-579, 2014. https://doi.org/10.1016/j.actbio.2013.10.036

TRÁVNÍČKOVÁ M, BAČÁKOVÁ L: Application of adult mesenchymal stem cells in bone and vascular tissue engineering. Physiol Res 67: 831-850, 2018. https://doi.org/10.33549/physiolres.933820

VANDROVCOVÁ M, BAČÁKOVÁ L: Adhesion, growth and differentiation of osteoblasts on surface-modified materials developed for bone implants. Physiol Res 60: 403-417, 2011. https://doi.org/10.33549/physiolres.932045

WANG QG, ZHOU P, LIU SF, ATTARILAR S, MA RLW, ZHONG YS, WANG LQ: Multi-scale surface treatments of titanium implants for rapid osseointegration: a review. Nanomaterials 10: article ID 1244, 2020. https://doi.org/10.3390/nano10061244

WENNERBERG A, ALBREKTSSON T: Effects of titanium surface topography on bone integration: a systematic review. Clin Oral Implants Res 20 (Suppl 4): 172-184, 2009. https://doi.org/10.1111/j.1600-0501.2009.01775.x

WU G, LI P, FENG H, ZHANG X, CHU PK: Engineering and functionalization of biomaterials via surface modification. J Mater Chem B 3: 2024-2042, 2015. https://doi.org/10.1039/C4TB01934B

XAVIER SP, CARVALHO PSP, BELOTI M, ROSA AL: Response of rat bone marrow cells to commercially pure titanium submitted to different surface treatments. J Dent 31: 173-180, 2003. https://doi.org/10.1016/S0300-5712(03)00027-7

YURTTUTAN ME, KESKIN A: Evaluation of the effects of different sand particles that used in dental implant roughened for osseointegration. BMC Oral Health 18: 47, 2018. https://doi.org/10.1186/s12903-018-0509-3

ZAREIDOOST A, YOUSEFPOUR M, GHASEME B, AMANZADEH A: The relationship of surface roughness and cell response of chemical surface modification of titanium. J Mater Sci Mater Med 23: 1479-1488, 2012. https://doi.org/10.1007/s10856-012-4611-9

ZOFKOVA I: Involvement of bone in systemic endocrine regulation. Physiol Res 67: 669-677, 2018. https://doi.org/10.33549/physiolres.933843

ZOFKOVA I, BLAHOS J: New molecules modulating bone metabolism - new perspectives in the treatment of osteoporosis. Physiol Res 66 (Suppl 3): S341-S347, 2017. https://doi.org/10.33549/physiolres. 933720

ZOFKOVA I, DAVIS M, BLAHOS J: Trace elements have beneficial, as well as detrimental effects on bone homeostasis. Physiol Res 66: 391-402, 2017. https://doi.org/10.33549/physiolres.933454 